DOI: https://doi.org/10.12797/Politeja.15.2018.54.09

Krzysztof SZEWIOR

Uniwersytet Warszawski

krzysztofszewior@uw.edu.pl

\title{
PROCES BOLOŃSKI - POMIĘDZY OCZEKIWANIEM I ŚRODOWISKOWYM ROZCZAROWANIEM?
}

ABSTRACT The Bologna Process - between expectation and academic disappointment? The article is an attempt to understand changes in European higher education over the last two decades and to describe them from the perspective of public policies and europeanization processes. This approach was reflected in the development of the OMC and the EHEA. They are the background for the Bologna process. The article attempts to prove that the Bologna Process - in the optics of political science - is an instrument for realizing the values and objectives of European policies, that they are building the European educational and scientific space as one of many EU internal markets.

Keywords: the Bologna process, the European Higher Education Area, higher education

Słowa kluczowe: proces boloński, europejski obszar szkolnictwa wyższego, szkolnictwo wyższe 
$\mathrm{P}$ roces boloński od niespełna 20 lat rozpala emocje środowiska akademickiego w Polsce i w Europie z uwagi na niesione wartości i wywoływane przez siebie skutki dla kształcenia czy szerzej: kultury akademickiej. Środowisko uniwersyteckie w zasadzie dostrzega tylko końcowy jego aspekt, tj. podział studiów, punkty ECTS, efekty kształcenia czy ramy kwalifikacji. Natomiast z perspektywy polityk publicznych można go uznać za środek i zewnętrzny przejaw budowania jednolitego i spójnego rynku wewnętrznego UE oraz realizacji unijnych celów modernizacji społeczno-gospodarczej. Z tego też względu szkolnictwo wyższe i politykę edukacyjną należy traktować jako element szerzej ujmowanej public and social policy, którą w ostatnim okresie prowadzi się w paradygmacie otwartej metody koordynacji. Wyrażają się one budowaniem sfery socjalno-społecznej o przeznaczeniu subsydiarnym, ochronnym, proinwestycyjnym. Szczególnym wymiarem polityki społecznej jest rynek pracy promujący pełne zatrudnienie, długie okresy zatrudnienia oraz wysokie współczynniki aktywności zawodowej.

Polityka rynku pracy przynależała pierwotnie do kompetencji państw członkowskich, np. TWE przewidywał rozwój skoordynowanych strategii zatrudnienia i potrzebę jego promocji dla osiągnięcia wysokiego współczynnika osób pracujących ${ }^{1}$. Również Europejska Strategia Zatrudnienia (urzeczywistniana od 2000 r.) miała dowartościować sferę pracy oraz wzmocnić ochronę socjalną ${ }^{2}$ Z kolei na podstawie procesu luksemburskiego Radzie Unii Europejskiej postawiono cztery wytyczne związane z poprawą: wzajemnego dostosowania sfer pracobiorców i pracodawców, zdolności zatrudnienia, wspierania przedsiębiorczości, równościowych relacji pomiędzy płciami ${ }^{3}$. Proces luksemburski okazał się preludium dla Otwartej Metody Koordynacji (OMK), w Lizbonie zdefiniowanej i przyjętej do prawa wspólnotowego, a od strategii lizbońskiej OMK stała się podstawowym unijnym instrumentem w sterowaniu reformami społeczno-politycznymi. Na szczycie w Sztokholmie w 2001 r. do OMK wprowadzono (poszerzone następnie w 2004 r.) kolejne obszary, w tym politykę edukacyjną. OMK jako element polityki spójności powinna prowadzić do wzrostu zatrudnienia, a jej celami uczyniono: konwergencję, regionalną konkurencyjność, zatrudnienie, terytorialną współpracę. W 2005 r. zmodyfikowano strategię lizbońską dla uzyskania poprawy współpracy pomiędzy państwami członkowskimi UE oraz jej instytucjamí W Lizbonie w 2000 r. postanowiono wspierać modernizację i usprawniać zarządzanie

1 Wersja skonsolidowana Traktatu ustanawiającego Wspólnotę Europejską, art. 1. W celu realizacji zadań określonych w art. 2 działalność Wspólnoty obejmuje, na warunkach i zgodnie z harmonogramem przewidzianym w niniejszym traktacie: 1) wspieranie koordynacji polityk zatrudnienia państw członkowskich w celu wzmocnienia ich efektywności poprzez realizację wspólnej strategii zatrudnienia; 2) przyczynianie się do osiągnięcia wysokiej jakości edukacji i kształcenia zawodowego oraz rozkwitu kultur państw członkowskich. Traktat ustanawiajacy Wspólnotę Europejską, Dz.U. UE 2006, C 321E, [online] http://oide.sejm.gov.pl/oide/index.php?option=com_content\&view=article\&i$\mathrm{d}=14436$ \&Itemid=436, 30 VI 2018.

2 H. Ribhegge, Europäische Wirtschafts- und Sozialpolitik, Heidelberg 2011, s. 198 i nast.

3 S. Sroka, R. Herbut, P. Sula, Dialog spoteczny na poziomie regionalnym. Raport z badań, Warszawa 2004, s. 20.

4 H. Ribhegge, Europäische Wirtschafts- und Sozialpolitik..., s. 199. 
ponadnarodowymi procesami politycznymi. Zasadami OMK stały się: wspólna identyfikacja celów i teleologiczne zarządzanie, ustalanie środków doń prowadzących, kooperacja i porównywalność. OMK powinna być promowana poprzez wymianę dobrych praktyk i miała okazać się instrumentem promocji norm i wartości europejskich ${ }^{5}$. Jej celem uczyniono integrującą spójność oraz konwergencję na najbardziej optymalnym poziomie z uwagi na cele strategicznego rozwoju.

Niestety przyjęte w UE rozwiązanie miało słabe strony, obrazujące napięcie pomiędzy instytucjami unijnymi i państwami narodowymi na polu kompetencji i decyzyjności. Ujawniła się także ich obiektywna słabość, a mianowicie (nie)zdolność sterowalności zmianą społeczną skoncentrowaną na realizacji celów rozwoju społecznego UE. Mając na uwadze zrównoważony rozwój Unii oraz pożądaną przewagę konkurencyjną, w programie UE 2020 zawarto istotne elementy odnoszące się do szeroko pojmowanego kształcenia. Wzrost i rozwój mają bazować na stale wzbogacanej wiedzy, na zharmonizowaniu nauczania oraz na innowacjach, wypływających ze sfery badawczo-rozwojowej i powiązanych z nią oraz inspirowanych otoczeniem społeczno-gospodarczym. W związku z tym na poziomie akademickim nieodzowne stało się zbudowanie - analogicznie do innych obszarów - otwartej i zestandaryzowanej przestrzeni. Ponieważ w UE polityka edukacyjna oraz szkolnictwa wyższego są domeną krajów członkowskich, należało stworzyć rozwiązanie pozwalające implementować w nich procesy europeizacji szkolnictwa wyższego. Dobrym rozwiązaniem, w obliczu dysponowania unijnym prawem miękkim i siłą oddziaływania politycznego, stała się OMK. W jej ramach zauważyć można równoczesne przenoszenie kompetencji z poziomu narodowego na unijny i naśladownictwo praktyk oraz ścieżek rozwoju innych państw, co stwarza wrażenie podmiotowości polityk krajowych ${ }^{6}$.

Strategia lizbońska (2000 r.) jednoznacznie ujmowała kształcenie przez pryzmat celów rozwojowych Europy. Wiedza miała być nośnikiem innowacyjności i wzrostu, a sprzyjać jej miały atrybuty cechujące analogicznie inne rynki UE. Użytkowy i usługowy walor wiedzy oraz kształcenia można dostrzec w obszarach wiodących odnowionej strategii lizbońskiej (2004 r.). Miały one służyć wzmacnianiu obszarów priorytetowych, np. powiązanych z rynkiem pracy, i przyczyniać się do rozwijania kompetencji zawodowych ${ }^{7}$.

Rolę UE na polu edukacji określono w art. 165 ust. 1 Traktatu o funkcjonowaniu Unii Europejskiej (TFUE):

Unia przyczynia się do rozwoju edukacji o wysokiej jakości, poprzez zachęcanie do wspótpracy między państwami cztonkowskimi oraz jeżeli to niezbędne, poprzez wspieranie

J.T. Weishaupt, Die Offene Methode der Koordinierung in der deutschen Sozialpolitik: Trojanisches Pferd, sozialpolitischer Beschleuniger oder vertane Chance?, „Zeitschrift für Sozialreform” 2013, vol. 59 , $\mathrm{nr}$ 1, s. 61- 84, [online] https://doi.org/10.1515/zsr-2013-0104; K. Szeląg, Koordynacja polityk gospodarczych w Unii Europejskiej, cz. II, „Bank i Kredyt” 2003, kwiecień, s. 25-37.

6 Prawo Unii Europejskiej z uwzględnieniem traktatu z Lizbony, red. A. Kuś, Lublin 2010, s. 191. Szerzej zob. K.-D. Borchardt, ABC prawa Unii Europejskiej, Luksemburg 2011.

Wytyczne dla Rady 2008/618 WE z 15/07/2008 dot. polityki zatrudnienia państw cztonkowskich na lata 2008-2010. 
i uzupetnianie ich dziatań, w petni szanujac odpowiedzialność państw cztonkowskich za treści nauczania i organizację systemów edukacyjnych, jak również ich różnorodność kulturowa i językowa [...].

Zgodnie z art. 165 ust. 2 TFUE w obszarze edukacji działania zmierzają do rozwoju wymiaru europejskiego w edukacji, np. poprzez: nauczanie języków, sprzyjanie mobilności, zachęcanie do uznawania dyplomów i okresów studiów, promowanie współpracy między placówkami edukacyjnymi, rozwój wymiany informacji o systemach edukacyjnych państw członkowskich ${ }^{8}$.

Europejski obszar szkolnictwa wyższego9 (EOSW, od 2010 r.) rozwija się podobnie jak inne rynki wewnętrzne UE. W minionym okresie charakteryzowała go zbieżność wielu cech z innymi rynkami. Na poziomie najbardziej ogólnym można je odnaleźć w sferze wartości, celów, funkcji wewnętrznych, a także w stosunku do otoczenia. Wspólny rynek europejski to obszar bez barier i ograniczeń wewnętrznych, zapewniający swobodny przepływ osób, towarów, usług, zorientowany na zrównoważony rozwój, konkurencyjność oraz społeczne włączenie ${ }^{10}$. Celem EOSW w chwili powstania było rozwijanie zdefiniowanych już wcześniej wartości ${ }^{11}$ : mobilności, zatrudnialności, drożności, badań naukowych zorientowanych na otoczenie społeczno-gospodarcze i powiązanych z nim. Zadania te zapisano w komunikacie z konferencji w Bukareszcie z 2012 r. Dla lepszego wdrażania procesu bolońskiego za ważne uznano silniejszą koncentrację na czynnik zapewniania i zarządzania jakością. Odnoszono go do wielu aspektów funkcjonowania uczelni, w tym do mobilności, studiów, losów zawodowych absolwentów. Ten katalog zadań wynikał z dostrzeżonej zmiany roli wiedzy i wykształcenia w indywidualnej biografii człowieka oraz w szerszym wymiarze społecznym, ich znaczenia w nowym modelu społeczeństwa informacyjnego oraz z potrzeby tworzenia innowacyjnej i międzynarodowo konkurencyjnej i zaawansowanej technologicznie gospodarki, a także posiadania rynku pracy z dobrze wykształconymi pracownikami. Aspiracją europejskich polityków było stworzenie jakościowej i konkurencyjnej przestrzeni edukacyjnej, otwartej na wielokulturowość i przepływ idei, zdolnej konkurować z innymi ośrodkami na polu dydaktycznym oraz badawczym.

Z perspektywy minionej dekady należy uznać, że EOSW przyczynił się do zreformowania narodowych systemów szkolnictwa wyższego w duchu ich europeizacji, zestandaryzował szereg procedur i ujednolicił struktury szkolnictwa wyższego. Tworząc wspólną przestrzeń, podążał za innymi rynkami wewnętrznymi UE, pozwalając utrzymać z nimi spójność i funkcjonalną przydatność. Istotnym wkładem w tworzenie europejskiego wymiaru nauczania są Europejskie Ramy Kwalifikacji, będące sposobem czytelnego „przełożenia” kwalifikacji zdobywanych w szkołach różnych państw

Traktat ofunkcjonowaniu Unii Europejskiej - wersja skonsolidowana, Dz.U. UE C 115, 9 V 2008.

http://www.procesbolonski.uw.edu.pl, 11 VI 2014.

10 Art. 26 ust. 2 TFUE (dawny art. 14 ust. 2 TWE). Traktat o Unii Europejskiej, tekst skonsolidowany uwzględniajacy zmiany wprowadzone Traktatem z Lizbony, Dz.U. 2004, 90.864/30. Szerzej zob. K. Tomaszewski, Rynek wewnętrzny Unii Europejskiej - szansą i wyzwaniem dla obywateli, „Studia Europejskie" 2003, t. 2.

11 Priorytety Leuven i Louvain-la-Neuve z 2009 r. 
na zestandaryzowany język ich opisu oraz klasyfikacji kompetencji. Wzmocniono tym samym odpowiedzialność szkół wyższych za profil i poziom nauczania, zaś rzeszy studiujących otworzono przestrzeń do mobilności na etapie kształcenia oraz później zatrudnienia zgodnie z posiadanymi i odbieranymi jednolicie kwalifikacjami.

W EOSW powinny funkcjonować szkoły wyższe posiadające zasoby i atuty pozwalające im na realizację dużego zakresu zadań edukacyjno-badawczych oraz wyuczania ról społecznych w paradygmacie społecznej odpowiedzialności. Celowościowy sposób powiązania z otoczeniem oraz relacje między uczelnią i jej partnerami społeczno-gospodarczymi oparte na wzajemnej niezależności i subsydiarnym oddziaływaniu miały przyczyniać się do zrównoważonego rozwoju. Należy zwrócić uwagę na fakt, iż orientowanie szkół wyższych na wymiar europejski i społeczno-biznesowy determinuje lojalność kształcenia wobec krajowego środowiska i jego wyzwań. Narodowych wyróżników jest coraz mniej, warto wskazać na: zglobalizowanie treści nauczania, obecność języka angielskiego jako wykładowego i publikacyjnego, umiędzynarodowienie grona studentów i anglojęzyczne ścieżki studiów, konieczność konkurowania pomiędzy uczelniami nie tylko w prestiżowych rankingach, lecz także o studentów ${ }^{12}$.

Stosunkowo wcześnie w świadomości decydentów ugruntowało się przekonanie o potrzebie trwałego zabezpieczenia jakości w sferze studiów i nauczania poprzez zmianę modelu zarządzania szkolnictwem czy uczelniami, tj. wykorzystania nowoczesnych biznesowych metod i narzędzi zapewniania jakości. W 2001 r. w Pradze powstała organizacja European Association for Quality Assurance in Higher Education (ENQA) ${ }^{13}$. Kolejne lata i konferencje pozwoliły budować - już na poziomie państw narodowych - systemy akredytacyjne ${ }^{14}$. W ostatnim okresie ważny jest rok 2015, kiedy przyjęto ustalenia europejskich ministrów w Erywaniu - The Standards and Guidelines for Quality Assurance in the European Higher Education Area (ESG), będące wspólną ramą referencyjną dla systemów zapewnienia jakości w europejskiej przestrzeni szkolnictwa wyższego ${ }^{15}$. Co do zasady odnoszą się one zarówno do wewnętrznego i pozauczelnianego systemu zapewniania i doskonalenia jakości, jak i do standardów jakościowych akredytujących agencji.

Odpowiedź szkolnictwa wyższego na postulaty synergii rozwoju z innymi wewnętrznymi rynkami UE przyszła w okresie milenijnego przełomu i znalazła wyraz w deklaracjach sorbońskiej oraz bolońskiej. W 1998 r. w Sorbonie cztery kraje porozumiały się w sprawie harmonizacji, mającej zastąpić europejską różnorodność. Ponieważ inne

12 Ch. de Montlibert, Universitätsreform und Begriffspolitik, [w:] Humbolts Albtraum. Bolonga-Prozess und seine Folgen, red. F. Schultheis, P.F. Cousin, M. Roca i Escoda, Konstanz 2008, s. 29-30.

13 G. Schreier, Qualitätssicherung als nationale Aufgabe mit europäischer Perspektive. Projekt Qualitätssicherung der Hochschulrektorenkonferenz, [w:] Internationalisierung = Evaluation + Akkreditierung? 3. Nationales Expertenseminar zur Qualitätssicherung Bonn, Wissenschaftszentrum, 7./8. September 2000, „Beiträge zur Hochschulpolitik” 2001, nr 8, s. 15-20.

14 D. Westerheijden, Akkreditierung im europäischen Kontext. Neuere Entwicklungen der Qualitätssischerung im europäischen Hochschulraum, [w:] Handbuch der Akkreditierung von Studiengängen. Eine Einführung für Hochschule, Politik und Berufspraxis, red. F. Bretschneider, J. Wildt, Bielefeld 2007, s. 105.

15 F. Börsch, Standards für Akkreditierungsverfahren. Akkreditierungsrat, [w:] Internationalisierung = Evaluation + Akkreditierung?..., s. 21-25. 
unijne rynki (wewnętrzne) już od lat 90. silnie się integrowały, stan utrzymującego się narodowego rozproszenia szkolnictwa wyższego był coraz większym utrudnieniem. Nowe podejście zdradzało konotacje z logiką zarządzania gospodarką i dopasowywania edukacji zarówno do rynku pracy, jak i do całościowego projektu unijnego ${ }^{16}$. Proces boloński wszedł jednocześnie w dwa zjawiska: globalizację i wspólną reakcję państw europejskich oraz rozwój otwartego rynku dla przemieszczania się ludzi, dóbr, usług. Deklaracje sorbońska i bolońska podkreślały wagę rozwijania EOSW, który powinien przyczynić się do poprawy jakości nauczania, uelastycznienia procesu kształcenia, wyzwolenia mobilności. Brakowało jednakże stosownych rozwiązań, procedur oraz narzędzi, czyniących przestrzeń akademicką iście europejską. Zaczęto więc usuwać bariery i ograniczenia, standaryzować, dotychczas krajowe, uniwersyteckie wyróżniki i systemy szkolnictwa wyższego. Działania te objęły strukturę studiów poprzez ich podział na poziom licencjacki i magisterski. Zapoczątkowano opis sylwetki absolwenta z uwagi na porównywalne kwalifikacje, nadawano analogiczne stopnie i tytuly zawodowe. Dla wzmocnienia mobilności wprowadzono system przenoszenia i uznawania osiągnięć oraz rozwijano specjalne programy promocji ${ }^{17}$.

Proces boloński zawierał fazę pluralistycznej inicjatywy i neoliberalno-ekonomicznego instrumentu polityki europejskiej, co znajduje potwierdzenie w puli atrybutów, w celach i języku opisu, w koncentrowaniu na zatrudnialności i systemowej oraz międzyuczelnianej konkurencyjności ${ }^{18}$. W 2003 r. w Berlinie proces boloński poszerzono o komponent zarządzania jakością, a strukturę studiów o trzeci stopień. Kolejne międzyrządowe konferencje wzmacniały powiązania środowiska naukowego i otoczenia oraz ułatwiały przenikanie tych dwóch sfer. Po Leuven (2009 r.) kontynuowano działania na rzecz większego otwarcia i drożności szkolnictwa oraz jego lepszego zorientowania na potrzeby szerszej niż narodowa przestrzeni społeczno-gospodarczej. Tak rozumiana ewolucja stanowiła odejście od narodowej perspektywy szkolnictwa akademickiego i jego zróżnicowania na podstawie dotychczasowych wyróżników ${ }^{19}$.

Proces boloński nie wszędzie na kontynencie był zjawiskiem awangardowym; np. w Niemczech wznowił zapoczątkowane wcześniej działania. Także kraje anglosaskie cechowała otwartość na umiędzynarodowienie, podział studiów ${ }^{20}$, autonomia kierunkowa i zewnętrzne wspomaganie uczelnianych działań projakościowych ${ }^{21}$. Szczególnie w ramach EOSW, ale posiłkując się procesem bolońskim, na kontynencie zaczęto silniej dbać o międzynarodową atrakcyjność studiów i badań naukowych. Poprawie miała ulec środowiskowa mobilność w ramach jednolitego i zharmonizowanego obszaru.

16 D. Westerheijden, Akkreditierung im europäischen Kontext..., s. 105, 108.

17 Deklaracja Bolonska. Szkolnictwo Wyższe w Europie. Wspólna Deklaracja Europejskich Ministrów Edukacji, zebranych $w$ Bolonii 19 czerwca $1999 r$.

18 U. Wuggenig, Eine Transformation des universitären Feldes: Der Bologna-Prozess in Deutschland und seine Vorgeschichte, [w:] Humbolts Albtraum..., s. 124.

19 R. Fantasia, Insider-Geschäfte auf dem universitären Markt der USA: Mechanismen der Elitereproduktion, [w:] Humbolts Albtraum..., s. 19 i nast. 
Proces boloński pozostawał integralnym elementem strategii lizbońskiej i miał realizować jej cel: sprawienie, by Europa była konkurencyjna, by rozwijała się dynamicznie i w sposób zrównoważony. Działania te miały spotęgować spójność społeczną oraz rozwój zatrudnienia. By oddziaływanie było skuteczne, należało silniej zintegrować politykę edukacyjną ze społeczno-gospodarczą na poziomie państw narodowych oraz procesów europejskich ${ }^{22}$. Nieodzowny okazał się odgórny polityczny nacisk ministrów, wspomagający włączenie szkolnictwa wyższego w realizację całościowych koncepcji rozwoju. Analogicznie do innych rynków wewnętrznych, i w tym przypadku konieczna okazała się sprawozdawczość z realizacji uprzednio wyznaczanych celów i osiągnięcia wymaganych standardów. W UE realizuje się tego typu nadzór np. przez europejskie semestry. W ramach nowego podejścia oraz celów strategicznych UE szkolnictwu wyższemu wyznaczono kierunki zmian w sferach dydaktycznej oraz badawczej, nie czyniąc z nich jednakże wartości autotelicznych, lecz nadając im status poniekąd ustugo$w y^{23}$. Celem procesu bolońskiego stało się stworzenie jednolitej, umiędzynarodowionej przestrzeni szkolnictwa wyższego o wysokim wskaźniku mobilności osób, o sile przyciągania atrakcyjnością oferty i jakości studiów. Wiarygodność miała być budowana poprzez transparentność i porównywalność, z kolei kompatybilność z otoczeniem zewnętrznym - poprzez wzajemne uznawanie się i subsydiarne wsparcie ${ }^{24}$.

Niestety, do tej puli atutów środowisko uniwersyteckie zebrało sporo zarzutów o systemowym charakterze.

Tab. 1. Zarzuty wobec procesu bolońskiego i drażliwe obszary nim wywołane

\begin{tabular}{|c|c|}
\hline $\begin{array}{l}\text { Zarzuty }{ }^{25} \text { wobec procesu bolońskiego: } \\
\text { - jest przykładem autorytarnej polityki typu } \\
\text { top-down; } \\
\text { - wprowadza logikę rynku do sfery szkolnictwa } \\
\text { wyższego; } \\
\text { - sprzyja rozwijaniu w szkolnictwie wyższym } \\
\text { kultury przedsiębiorczości, zarządzaniu przy } \\
\text { wykorzystaniu nauk o zarządzaniu; } \\
\text { - sprzyja ekonomizacji kwestii edukacyjnych } \\
\text { i badawczych; } \\
\text { - nie promuje mobilności studenckiej w oczeki- } \\
\text { wanym stopniu; } \\
\text { - standaryzuje porównywalność dyplomów i stu- } \\
\text { diów nie tyle na bazie ich realnej wartości, ile }\end{array}$ & $\begin{array}{l}\text { Drażliwe obszary wywołane procesem } \\
\text { bolońskim²6: } \\
\text { - naruszenie struktury studiów i zmodyfikowa- } \\
\text { nie celów nauczania; } \\
\text { - utrata zaufania do środowiska w zakresie celów } \\
\text { i jakości kształcenia; } \\
\text { - rozwój biurokracji i przewaga pionu admini- } \\
\text { stracyjno-biurokratycznego; } \\
\text { - wprowadzenie wewnętrznych mechanizmów } \\
\text { zarządzania jakością oraz zewnętrznej (i kosz- } \\
\text { townej) oceny jakości studiów i nauczania; } \\
\text { - uzależnienie finansowania od wyników w sfe- } \\
\text { rze badawczej oraz dydaktycznej; } \\
\text { - konkurencja pomiędzy uczelniami. }\end{array}$ \\
\hline
\end{tabular}

Źródło: opracowanie własne.

22 S. Garcia, Die Konstruktion des europäischen Hochschulraums, [w:] Humbolts Albtraum..., s. 63-64.

23 U. Wuggenig, Eine Transformation..., s. 123-124, 147; S. Garcia, Die Konstruktion..., s. 68.

24 F. Schultheis, Ein Resïmee: Welche Universität für welches Europa?, [w:] Humbolts Albtraum..., s. 188$-189$.

25 Tamże, s. 189-190.

26 Tamże, s. 189. 
Powyższy wykaz zarzutów wydaje się uzasadniać stwierdzenie, że proces boloński jest nie tylko funkcją europeizacji i neoliberalnej globalizacji szkolnictwa wyższego. Przyczynia się on do zmiany kultury akademickiej i, szerzej, intelektualnej ${ }^{27}$. Zmienia on również status nauki, szkół wyższych oraz samych akademików. Krytycy opisywanych przeobrażeń dostrzegają zmianę ról i ograniczenie niezależności wewnętrznej oraz zewnętrznej, postrzegania i społecznej pozycji. Owe przemiany są konsekwencją ewolucji otoczenia uczelni, która niesie ze sobą szereg nakładających się zjawisk: urynkawianie, popularyzację ryzyka, usieciowienie, zmiany modelu zarządzania państwem ${ }^{28}$. Procesy te skutkują przesunięciem uprawnień i władzy pomiędzy sferą polityki i ekonomii, przestrzenią krajową i ponadnarodową. Znajduje to odbicie również w szkolnictwie wyższym i wyraża się nie tyle prostym i namacalnym odebraniem uprawnień uczelniom, ile przydzieleniem im nowych zadań i ról, zobowiązaniem do konsultacji i do (zinstytucjonalizowanej) kooperacji z otoczeniem społeczno-gospodarczym, do sprawozdawczości, do poddawania się zewnętrznej ocenie ${ }^{29}$.

Krytycy dostrzegają w procesie bolońskim słabości i uchybienia o charakterze systemowym. Zarzuca się mu brak prawnej i akademickiej legitymizacji, szybkie tempo wprowadzanych zmian z pominięciem środowiskowych konsultacji, biurokratyzację. Proces boloński zredukował przestrzeń wolności nauczania i jednocześnie stanowił prawny gorset w odniesieniu do struktury studiów. Standaryzując poziom dyplomowania, sprowadzono uniwersytety do roli „szkółek”; w ramach postępowania akredytacyjnego stwierdza się ponadto, iż szkoły „mniejszego formatu” również zapewniają kształcenie na wymaganym ,jakościowym” akademickim poziomie. Dla sceptyków nie do końca przekonujące były zmiany dokumentujące poziom nauczania, inkluzyjność studiów, pułap mobilności studentów i nauczycieli. Podkreślają oni jednocześnie fundamentalną zamianę autonomii pojedynczych naukowców w niezależność instytucjonalną uczelni. Ale i ona jedynie zmieniła adresata lojalności. Niezależność od państwa przeszła w uzależnienie od sfery finansowo-gospodarczej, co nie powinno dziwić z uwagi na fakt, że obecnie polityka jeszcze wyraźniej stała się funkcją ekonomii. Takie nowe usytuowanie szkoły wyższej kłóci się z jej dotychczasową specyfiką jako instytucji autonomicznej, samorządnej, zdecentralizowanej na poziomie jednostek dydaktyczno-badawczych zagospodarowujących określony obszar wiedzy ${ }^{30}$. Utrata niezależności widoczna jest w pewnym względzie we wprzęgnięciu środowiska akademickiego w realizację strategicznych wyzwań Europy na rzecz rozwoju społeczeństwa kognitywnego i gospodarki opartej na wiedzy.

Uniwersytety od przynajmniej dwóch dekad podlegają silnym procesom umasowienia przy jednoczesnym nieproporcjonalnie niższym wsparciu finansowym ze strony

F. Schultheis, P.-F. Cousin, M. Roca i Escoda, Konstruktion und Folgen eines europäischen Hochschulsystems, [w:] Humbolts Albtraum..., s. 7-18.

28 F. Schultheis, Ein Resümee..., s. 188-189.

29 B. Kaufmann, Akkreditierung als Mikropolitik. Zur Wirkung neuer Steuerungsinstrumente an deutschen Hochschulen, Wiesbaden 2012, s. 11-12.

30

U. Wuggenig, Eine Transformation..., s. 148-153. 
instytucji państwa i presji społeczno-gospodarczej na dostarczanie wykwalifikowanej kadry. Niestety nie wszędzie udało się pogodzić szerokie otwarcie wrót rekrutacyjnych poprawiające współczynniki skolaryzacji z zachowaniem należytej jakości nauczania i przekazywania wymaganych kompetencji. Dlatego w szkołach wyższych należy widzieć nie tylko sprawcę tego stanu rzeczy, lecz także ofiarę strukturalnego niezawinionego niedopasowania.

Ostatnie dekady rozwoju szkolnictwa wyższego pozwalają patrzeć nań jak na każdy inny rynek wewnętrzny UE, podlegający procesom europeizacji. Cechuje go podobna ścieżka rozwoju, można go opisać przy pomocy tych samych pojęć. W tym rozwoju zmianie uległy usytuowanie i rola państw narodowych względem kształtowania niezależnej polityki edukacyjnej i badawczej. Państwa narodowe zachowały wprawdzie swą podstawową podmiotowość w sferze stanowienia prawa i nadzo$\mathrm{ru}$, jednakże $\mathrm{w}$ wielu aspektach są one jedynie przeniesieniem na grunt narodowy przepisów czy wręcz standardów europejskich/unijnych (np. ramy podziału, punkty ECTS, uznawanie kwalifikacji spoza szkolnictwa wyższego, poddawanie się akredytacji z uwzględnieniem ESG). Wskutek realizacji projektów społecznej modernizacji, obejmujących czynnik wiedzy i wykształcenia, zauważalny jest proces transferu kompetencji zarówno do instytucji unijnych, jak i w ramach układu sieciowego. Skutkuje to rozproszeniem uprawnień, władzy i wpływu. $Z$ uwagi na fakt postulowanego wiązania kształcenia z potrzebami społecznego środowiska powinno się dążyć nie tyle do ujednolicania, ile do harmonizacji i, na tej podstawie, do wewnątrz- i zewnątrzsystemowej konkurencyjności.

Szkolnictwu akademickiemu wyznaczono jednocześnie kilka ról do odegrania. W stosunku do społeczeństwa i nauki opisuje je obowiązek rozwijania kapitału intelektualnego i społecznego, poszerzania zasobów wiedzy i doskonalenia poznania naukowego. Wzmocniono dostęp do systemów nauczania na kolejnych jego poziomach, szczególnie przez pryzmat europejskich wartości społecznych, czyniąc z dobrego dyplomu przesłankę lepszej pracy, wynagrodzenia, wyrównanego statusu. Wiedza i umiejętności traktowane jako dobro i środek dla inkluzji społecznej oraz ekonomicznego bezpieczeństwa stały się równocześnie istotnym czynnikiem rozwoju gospodarki i procesów modernizacji. Siłą rzeczy musiał spowszechnieć dyplom ukończenia szkoły wyższej. Ale czy się zdewaluował?

Proces boloński z upływem czasu stawał się instrumentem tworzenia i oddziaływania EOSW. Na tym polu do głosu doszły ekonomia i nauki o zarządzaniu. Zmianie uległa relacja uniwersytetu z otoczeniem, przyjmując postać kooperacyjną i konsensualną. Widoczne było także urynkowienie i zderegulowanie szeregu aspektów ${ }^{31}$. W sposób naturalny otworzyło to przestrzeń do rywalizacji pomiędzy uczelniami o studentów,

31 P. Teixeira, The Tortuous Ways of the Market: Looking at the European Integration of Higher Education from an Economic Perspective, „LEQS Paper”, nr 56, London 2013. 
o dostęp do środków niezbędnych na badania naukowe i działalność publikacyjną, o pozycjonowanie na listach rankingowych.

\section{BIBLIOGRAFIA}

Borchardt K.-D., ABC prawa Unii Europejskiej, Luksemburg 2011.

Börsch F., Standards für Akkreditierungsverfahren. Akkreditierungsrat, [w:] Internationalisierung = Evaluation + Akkreditierung? 3. Nationales Expertenseminar zur Qualitätssicherung Bonn, Wissenschaftszentrum, 7./8. September 2000, „Beiträge zur Hochshulepolitik” 2001, nr 8.

Chmielecka E., Proces boloński i krajowe ramy kwalifikacji dla szkolnictwa wyższego, „Studia BAS" 2013, nr 3.

Deklaracja Bolońska Szkolnictwo Wyższe w Europie Wspólna Deklaracja Europejskich Ministrów Edukacji, zebranych w Bolonii 19 czerwca 1999.

Fantasia R., Insider-Geschäfte auf dem universitären Markt der USA: Mechanismen der Elitereproduktion, [w:] Humbolts Albtraum. Bolonga-Prozess und seine Folgen, red. F. Schultheis, P.-F. Cousin, M. Roca i Escoda, Konstanz 2008.

Garcia S., Die Konstruktion des eurpäischen Hochschulraums, [w:] Humbolts Albtraum. Bolonga-Prozess und seine Folgen, red. F. Schultheis, P.-F. Cousin, M. Roca i Escoda, Kon$\operatorname{stanz} 2008$.

Kaufmann B., Akkreditierung als Mikropolitik. Zur Wirkung neuer Steuerungsinstrumente an deutschen Hochschulen, Wiesbaden 2012.

Montlibert Ch. de, Universitätsreform und Begriffspolitik, [w:] Humbolts Albtraum. Bolonga-Prozess und seine Folgen, red. F. Schultheis, P.-F. Cousin, M. Roca i Escoda, Konstanz 2008.

Prawo Unii Europejskiej z uwzględnieniem traktatu z Lizbony, red. A. Kuś, Lublin 2010.

Ribhegge H., Europäische Wirtschafts- und Sozialpolitik, Heidelberg 2011.

Schreier G., Qualitätssicherung als nationale Aufgabe mit europäischer Perspektive. Projekt Qualitätssicherung der Hochschulrektorenkonferenz, [w:] Internationalisierung $=$ Evaluation + Akkreditierung? 3. Nationales Expertenseminar zur Qualitätssicherung Bonn, Wissenschaftszentrum, 7./8. September 2000, „Beiträge zur Hochschulpolitik” 2001, nr 8.

Schultheis F., Ein Resümee: Welche Universität für welches Europa?, [w:] Humbolts Albtraum. Bolonga-Prozess und seine Folgen, red. F. Schultheis, P.-F. Cousin, M. Roca i Escoda, Konstanz 2008.

Schultheis F., Cousin P.-F., Roca i Escoda M., Konstruktion und Folgen eines europäischen Hochschulsystems, [w:] Humbolts Albtraum. Bolonga-Prozess und seine Folgen, red. F. Schultheis, P.-F. Cousin, M. Roca i Escoda, Konstanz 2008.

Sroka J., Herbut R., Sula P., Dialog spoteczny na poziomie regionalnym. Raport z badań, Warszawa 2004.

Standards and Guidelines for Quality Assurance in the European Higher Education Area (ESG) Approved by the Ministerial Conference in May 2015. III. Annex: Summary list of standards.

Szeląg K., Koordynacja polityk gospodarczych w Unii Europejskiej, cz. II, „Bank i Kredyt” 2003, kwiecień. 
Teixeira P., The Tortuous Ways of the Market: Looking at the European Integration of Higher Education from an Economic Perspective, „LEQS Paper”, nr 56, London 2013.

Tomaszewski K., Rynek wewnętrzny Unii Europejskiej - szansq̨ i wyzwaniem dla obywateli, „Studia Europejskie" 2003, t. 2.

Traktat o Unii Europejskiej - tekst skonsolidowany uwzględniajacy zmiany wprowadzone Traktatem z Lizbony, Dz.U. UE 2004, 90.864/30.

Weishaupt J.T., Die Offene Methode der Koordinierung in der deutschen Sozialpolitik: Trojanisches Pferd, sozialpolitischer Beschleuniger oder vertane Chance?, „Zeitschrift für Sozialreform" 2013, vol. 59, nr 1, [online] https://doi.org/10.1515/zsr-2013-0104.

Westerheijden D., Akkreditierung im europäischen Kontext. Neuere Entwicklungen der Qualitätssischerung im europäischen Hochschulraum, [w:] Handbuch der Akkreditierung von Studiengängen. Eine Einführung für Hochschule, Politik und Berufspraxis, red. F. Bretschneider, J. Wildt, Bielefeld 2007.

Wuggenig U., Eine Transformation des universitären Feldes: Der Bologna-Prozess in Deutschland und seine Vorgeschichte, [w:] Humbolts Albtraum. Bolonga-Prozess und seine Folgen, red. F. Schultheis, P.-F. Cousin, M. Roca i Escoda, Konstanz 2008.

Dr hab. Krzysztof SZEWIOR, absolwent politologii, pracownik Instytutu Europeistyki Uniwersytetu Warszawskiego. Członek Polskiego Towarzystwa Nauk Politycznych, KNP PAN, PKA. Praca naukowa oraz na polu dydaktycznym koncentruje się na zagadnieniach społecznych państw niemieckiego obszaru językowego oraz Unii Europejskiej. Szczególnymi obszarami badawczymi są: model społeczny w procesach transformacji systemowej; szkolnictwo wyższe w kontekście Europejskiego Obszaru Szkolnictwa Wyższego. 